\title{
Small business management and environmental engagement
}

\section{Ana Rita Sampaio , Rhodri Thomas \& Xavier Font}

To cite this article: Ana Rita Sampaio , Rhodri Thomas \& Xavier Font (2012) Small business management and environmental engagement, Journal of Sustainable Tourism, 20:2, 179-193, DOI: 10.1080/09669582.2011.602193

To link to this article: https://doi.org/10.1080/09669582.2011.602193

册Published online: 10 Aug 2011.

Submit your article to this journal

Llll Article views: 2675

Citing articles: 28 View citing articles 지 


\title{
Small business management and environmental engagement
}

\author{
Ana Rita Sampaio ${ }^{\mathrm{a} *}$, Rhodri Thomas ${ }^{\mathrm{b}}$ and Xavier Font ${ }^{\mathrm{c}}$ \\ ${ }^{a}$ Centre for Geographical Studies, University of Lisbon, Portugal; ${ }^{b} U K$ Centre for Events \\ Management, Leeds Metropolitan University, UK; ${ }^{c}$ International Centre for Responsible Tourism, \\ Leeds Metropolitan University, UK
}

(Received 23 June 2010; final version received 28 June 2011)

\begin{abstract}
Small firms in tourism are characterised by informal approaches to management, allowing their owners to meet a variety of often overlapping business and personal goals. Environmental certification schemes generally require members to subscribe to formal environmental management systems (EMS), even when aimed at small business operators. This paper examines in detail the managerial approaches of a small group of owner-managers who are operating within the approximately 3000-member Green Tourism Business Scheme (GTBS) available in the UK and Ireland. The findings suggest that the type of environmental practices adopted most willingly reflect the formality of management within the business and the owner-managers' various backgrounds, values, reasons to be in business, expectations from acting and their understanding of the "environment". It finds that the "Plan-Do-Check-Review" approach of most EMS does not easily relate to the complex motivations and needs of the world of small business. The paper concludes that environmental engagement is more likely to be fostered if owner-managers' managerial approaches and assumptions are better understood and that shared visions for environmental engagement are encouraged through informed dialogue. Both economic benefits and the fostering of "feel good" factors should be stressed if small tourism businesses are to adopt EMS programmes.
\end{abstract}

Keywords: small tourism businesses; managerial approaches; environmental engagement; qualitative research; certification

\section{Introduction}

Recent reviews of research on small firms in tourism (e.g. Morrison, Carlsen, \& Weber, 2010; Thomas, Shaw, \& Page, 2011) have bemoaned the lack of progress in understanding the factors that influence their environmental engagement. Indeed, this research limitation extends to small businesses in general (Blackburn, 2009). The intensity of research activity and debate on other aspects of sustainability in tourism, such as climate change (e.g. Scott, 2011; Weaver, 2011) or policy interventions (e.g. Dredge \& Whitford, 2010; Getz, 2009), has not materialised in the context of small firms. This probably reflects no more than the marginal position such organisations occupy in the collective minds of tourism scholars. However, the lack of enquiry is unsatisfactory given the preponderance of ownermanaged enterprises in tourism and, therefore, the potential damage they may inflict on the environment.

This paper builds on the sporadic attempts that have been made to create a knowledge base about small firms and environmental engagement (e.g. Ateljevic \& Doorne, 2000;

\footnotetext{
*Corresponding author. Email: ana.rita.sampaio@gmail.com; sampaio@campus.ul.pt
} 
Dewhurst \& Thomas, 2003; Horobin \& Long, 1996; Tzschentke, Kirk, \& Lynch, 2008). Early explanations for the perceived limited environmental activity of small firms tended to emphasise the "busyness" of owner-managers or their need to concentrate on day-to-day management (McKercher \& Robbins, 1998). Unfamiliarity with the environmental and social consequences of their operations and how they might be mitigated have also been highlighted (Clarke, 2004; Horobin \& Long, 1996; Tilley, 2000), as has the lack of financial resources available to invest in environmental improvements (Vernon, Essex, Pinder, \& Curry, 2003). Against this backdrop, it is perhaps not surprising that the efforts of various agencies to develop environmental guidelines or "action packs" for small tourism enterprises have generally failed to engage their target audiences (Dewhurst \& Thomas, 2003; Forsyth, 1995). Although the business imperatives may remain, existing explanations of variable rates of environmental engagement now incorporate significantly wider dimensions.

Following a review of existing research, this paper examines the connections between how businesses are managed and their adoption of environmental practices. This relationship is explored via a study of members of the sustainability certification scheme, the Green Tourism Business Scheme (GTBS). Although it operates only in the UK and Ireland, it is the largest sustainable tourism certification scheme in the world with nearly 3000 certified enterprises, most of them small and medium sized (GTBS, 2011). By focusing on members of this scheme, the study sought to provide an account of the differential level of environmental engagement among a constituency of businesses that had expressed some degree of concern for the environment. The study did not, therefore, seek to cast light on the behaviour of small business owners who were not at all disposed to incorporating environmental considerations into their business practices.

\section{Small firms in tourism}

Most small tourism businesses are characterised by their informality. Few articulate formal goals or even business plans (Getz \& Carlsen, 2000), and most owner-managers tend to focus their attention on everyday activities rather than long-term planning (Beaver, 2002; Hukkinen, 1995; McKercher \& Robbins, 1998; Thomas, 1998). Several commentators have noted that small family businesses also usually adopt informal practices, which can be both advantageous and disadvantageous to business performance (Getz \& Carlsen, 2005; Peters $\&$ Buhalis, 2004). Although a less formal approach to business management may have the advantage of allowing flexibility and the ability to react quickly to the needs of the business, it may also result in inaccurate record keeping (e.g. book keeping) and suboptimal business performance (Peters \& Buhalis, 2004).

It is now well documented that the motivations for running small tourism businesses are numerous. For some, profit and growth are defining features, whereas for others, so-called lifestyle motivations predominate (Carlsen, Morrison, \& Weber, 2008; DiDomenico, 2005). Lifestyle motivations are not usually defined precisely in the literature, but are generally taken to mean matters relating to quality of life and business location. In their early work, Shaw, Williams, and Greenwood (1987) suggested that small business owners made a trade-off between commercial and lifestyle activities. They went on to note that "success" for each business owner was then defined according to where they located themselves on a continuum which had growth and lifestyle as opposite ends. More recently, several commentators have emphasised the role that values play in decision-making within such organisations, suggesting that some business owners may well have strong commercial orientations simultaneously with a desire to live a certain lifestyle (see, e.g., Ateljevic \& Doorne, 2000; Carlsen et al., 2008; Mottiar, 2007; Shaw \& Williams, 2004). 
Morrison, Carlsen, and Weber's (2008) review re-problematised the notion of lifestyle business and provided a useful summary of what is understood about what they now term "lifestyle-oriented small tourism (LOST) firms". They draw attention to a range of non-economic factors that influence the setting up of such businesses, the motivations, meanings and values attached to business practices, and how these differ in contrasting socio-economic settings. Sweeney and Lynch's (2009) research on "commercial home owners" (i.e. very-small-accommodation providers using their own home for tourism purposes) extends the analysis to those operating in that sector. There can be little doubt that these ways of conceptualising small tourism firms, which are much more attuned to the lived reality of owner-managers than is allowed for in neo-classical economics, are valuable. However, the concept remains somewhat fuzzy (Thomas et al., 2011), with much research remaining to be done to understand the nuances of behaviour among this broad category of firms (Morrison et al., 2008).

Much of the literature on environmental engagement and small firms in tourism has tended to focus on understanding barriers to participation in programmes designed to change behaviour (Palmer, 2000). Public policy in this respect has had a marginal impact, unless regulatory, because it generally fails to relate to the "world" of the owner-manager (Dewhurst \& Thomas, 2003; Tzschentke et al., 2008). This includes a failure to recognise that values play a key role in decision-making (e.g. Ateljevic \& Doorne, 2000; Dewhurst \& Thomas, 2003; Tzschentke et al., 2008) and that policy measures which fail to harness such values are unlikely to achieve their aims. It is also evident that the context and circumstances of individual businesses influence their disposition towards environmental engagement (e.g. Duc, 2009; Kokkranikal \& Morrison, 2002). This has led some to suggest typologies of environmental business practice (e.g. Dewhurst \& Thomas, 2003). To date, little research has been undertaken to examine the impact of formal environmental management systems (EMS) on small firms' behaviour, the focus of this paper.

\section{Small tourism businesses and environmental management systems}

Sustainability and environmental certification schemes, such as GTBS, tend to adopt formal EMS approaches even when they apply to small firms (Font, 2002). EMS generally encompass the planning, implementation, checking and application of corrective actions, followed by a management review (Plummer \& FitzGibbon, 2004). An analysis of the criteria for 59 sustainable tourism certification programmes shows that around $40 \%$ of the criteria refer to generic management actions such as developing a sustainability policy and ensuring that procedures are in place for the identification and correction of impacts, combined with minimum threshold performance criteria (Font \& Bendell, 2002). Despite a growing literature trying to adapt EMS to the tourism industry (International Hotels Environment Initiative [IHEI], 2005; Tribe, Font, Griffiths, Vickery, \& Yale, 2000), there are issues that have led some authors to suggest that EMS approaches may be ill-suited to small businesses (Gerstenfeld \& Roberts, 2000) for several reasons.

First, there is the problem of the owner-managers' low levels of environmental awareness and "ecoliteracy" (Chan, 2011; Tilley, 2000; Vernon et al., 2003). Anglada's (2000) study reveals that business managers are not particularly knowledgeable about scientific environmental matters and have limited access to information about environmental problems. Thus, the identification of environmental issues, while being a crucial initial step in the implementation of EMS, may constitute a real difficulty for owner-managers. As Anglada (2000) observes, the majority of managers do not have embedded in their approach to running their business a notion of what an integrated system is and so they 
attribute more importance to occasional environmental problems than to structural ones. The owner-managers' lack of knowledge about identifying business operations harmful to the environment is not a negligible problem.

The second issue with regard to the suitability of EMS is related to the nature of small firms and their access to human (including managerial expertise) and financial resources. The majority of small businesses in tourism employ one or two members of staff, which are generally the owner-manager or the co-entrepreneur/copreneur. Morrison defines copreneurs as a husband and wife "that take all decisions and deal with most of the work assisted by very few staff, many of whom are part-time" (2006, p. 200). The procedures based on "Check and Act" reviews may require environmental awareness and skills, time, and financial resources that are limited in small tourism businesses (McKeiver \& Gadenne, 2005). Even associated administrative tasks, such as keeping records of energy and water consumption, may prove difficult to implement, especially if they collide with lifestyle goals because of the need to allocate extra time and effort to those tasks (Morrison et al., 2008; Peters \& Buhalis, 2004).

The availability of information, advice and adequate funding to assist the implementation of environmental practices has also been seen by some as an important limiting factor on wider environmental engagement among small firms in tourism (Chan, 2011; Revell \& Rutherfoord, 2003). It has been argued that external barriers to the implementation of EMS may include variations in the verifiers' approach to system validation, the lack of accessible financial support, the lack of a central source of environmental legislation information, poor-quality information and conflicting guidance (Darnall \& Edwards, 2006; Hillary, 2000).

Being able to engage fully in a scheme such as GTBS may be influenced by the extent to which its participants share the same managerial approach and goals as are fostered by the scheme. Standards that emphasise the "Plan-Do-Check-Review" process have been criticised elsewhere for both not guaranteeing sustainability and making certification inaccessible to small firms because they find the standards ambiguous and expect more straightforward guidance and support than they feel they will be given (Chan, 2011; Honey, 2002). The strongest arguments for this have come from studies carried out in developing countries. Medina's ethnographic study suggests that sustainability criteria have "multiple and contested meanings" (2005, p. 293), with different interpretations of key issues such as "local" and "participation" between the local stakeholders and certification efforts, backing up Yanow's (2000) point that policy development and analysis should be grounded in the views of those affected by it. Vivanco (2007) explains how indigenous voices are absent in the development of standards and certification programmes, echoing calls for local decision-making participation to really be incorporated into ecotourism certification (Jamal, Borges, \& Stronza, 2006). The same can be said of tourism companies that are marginalised from the process of setting up criteria or systems for not being the key target market, resulting in inequitable access to certification. There is evidence from Australia to Central America that small firms are more likely to be in this marginalised group (Ingram, 2007; Medina, 2005; Thwaites, 2007; Vivanco, 2007). The remainder of this paper reports the findings of a project that examined the influence of managerial approaches on environmental engagement in small tourism firms when part of a scheme such as GTBS.

The GTBS started as a VisitScotland Quality Grading Scheme in 1997 (GTBS, 2011; Tzschentke et al., 2008). VisitScotland is a government-backed agency charged with marketing tourism to and within Scotland, encouraging the provision of tourist information and providing quality assurance and advice to the industry (see Lane, 2009). 
Table 1. Criteria domains and aims of the ecolabel.

\begin{tabular}{|c|c|}
\hline Criteria domain & Aim \\
\hline Compulsory & $\begin{array}{l}\text { To comply with environmental legislation and to be committed to } \\
\text { continuous improvement in environmental performance }\end{array}$ \\
\hline $\begin{array}{l}\text { Management and } \\
\text { marketing }\end{array}$ & $\begin{array}{l}\text { To demonstrate sound environmental management, including staff } \\
\text { awareness, specialist training, monitoring and record keeping }\end{array}$ \\
\hline $\begin{array}{l}\text { Social involvement and } \\
\text { communication }\end{array}$ & $\begin{array}{l}\text { To communicate environmental actions to customers via several } \\
\text { channels (e.g. green policy, promotion of environmental efforts on } \\
\text { the website, education, and community and social projects) }\end{array}$ \\
\hline Energy & $\begin{array}{l}\text { To have efficient lighting, heating, appliances and insulation; use of } \\
\text { renewable energy }\end{array}$ \\
\hline Water & $\begin{array}{l}\text { To be efficient via good maintenance, low-consumption appliances, } \\
\text { flush offset, rainwater harvesting and the use of eco-cleaners }\end{array}$ \\
\hline Purchasing & $\begin{array}{l}\text { To purchase environmentally friendly goods and services, such as } \\
\text { products made from recycled materials, and use and promote local } \\
\text { food and drink }\end{array}$ \\
\hline Waste & $\begin{array}{l}\text { To minimise waste by glass, paper, card, plastic and metal recycling, } \\
\text { having supplier take-back agreements, dosing systems and } \\
\text { composting }\end{array}$ \\
\hline Transport & $\begin{array}{l}\text { To minimise visitors' car use by promoting a local and national public } \\
\text { transport service, cycle hire and the use of alternative fuels. }\end{array}$ \\
\hline $\begin{array}{l}\text { Natural and cultural } \\
\text { heritage }\end{array}$ & $\begin{array}{l}\text { To have on-site measures with the purpose of enhancing biodiversity, } \\
\text { such as wildlife gardening, growing native species, nesting boxes and } \\
\text { providing information to visitors on local wildlife }\end{array}$ \\
\hline Innovation & $\begin{array}{l}\text { To have any good and best practice actions to increase business } \\
\text { sustainability that are not covered elsewhere }\end{array}$ \\
\hline
\end{tabular}

Source: GTBS (2011).

In 2001, the not-for-profit organisation, Green Business UK Ltd., was established to deliver the GTBS, which provides auditing, advisory and membership services to tourism businesses (GTBS, 2011). Targeting a wide range of business types (e.g. accommodation providers, visitor attractions, corporate offices), this scheme encompasses a significant number of independently owned small firms (GTBS, 2011; Tzschentke et al., 2008). The ecolabel's criteria focus on 10 different areas, notably compliance with legislation, good environmental management (e.g. staff awareness, specialist training, monitoring and record keeping), social involvement and communication, energy, and innovation (Table 1) (GTBS, 2011). Some of the specific measures that bed-and-breakfast (B\&B) accommodation providers might adopt under an EMS such as this are towel agreements, energy, waste and water monitoring, low-energy bulbs, use of small kettles, high-efficiency boilers and installation of solar panels. Members are reassessed through an auditing process every two to three years, based upon a set of regularly updated standards (GTBS, 2011). Small businesses using the ecolabel are then expected to develop their activity within the goals set by the scheme, notably to make business operations more sustainable while still delivering a high-quality service. Membership categories of gold, silver or bronze are awarded on the basis of the performance revealed by the audits.

\section{Methodology}

The aim of the study was to understand the dynamics of small business activity when operating within an EMS. A detailed qualitative design was appropriate because of the poor 
state of current knowledge and the need to gain access to the day-to-day practices and values of those operating such businesses. As numerous commentators have made clear, the rules that guide sampling in quantitative research do not apply for detailed qualitative enquiry of this kind (e.g. Patton, 2002; Yin, 2009). The key issues are to ensure that participants meet the stipulated criteria. In this case, nine small-scale accommodation providers (B\&B) in Scotland were selected for detailed qualitative enquiry. ${ }^{1}$ The participants were selected purposively primarily on the basis that they belonged to a particular membership category (three each from gold, silver and bronze), though they reflected variety in gender, age and business location (see Table 2). The specific choice was also influenced by the availability of additional documentation (such as GTBS inspection reports) and knowledge from a range of key informants, including GTBS staff, about aspects of the business that might be particularly interesting for the purposes of this study. Clearly, the intention was not to create a sample that was statistically representative of the wider population but to create an opportunity to examine in detail the practices of "engaged" business owners with a view to enhancing what is currently understood about the environmental practices of small firms in tourism (Yin, 2009).

Data collection involved visiting each business and interviewing the owner-managers, undertaking direct observation by staying at the accommodation and collecting documents such as leaflets, "green files" and guest books. Site audit reports undertaken by GTBS were also used to gain an additional perspective on the practices adopted. Conducting the interviews at the business, or more technically, in the "natural setting" of the case (Yin, 2009) allowed the gathering of contextual data via informal observations of the general condition of the rooms, the existence of energy- and water-saving appliances (e.g. energysaving light bulbs, refreshments packaging), local and environmental information available to guests, the location of the certification award (hidden or clear) and the environmental policy on display, as well as the type of products used for breakfast (e.g. local produce, fair trade).

Participants were informed about the research objectives and the confidential use of the information. Hence, they gave their consent to audio-recording of interviews for research purposes. The interviews followed a conversational style, carried out at the most suitable time and place for the owner-managers. The potential for researcher bias was minimised by presenting the owner-managers with a summary of narratives. The interviewees had then the opportunity to confirm or challenge their contents, as well as to provide clarification when necessary. This procedure was also used to ensure interpretative validity. Full interview verbatim transcripts were produced to ease the interpretation of the data and the selection of quotes for illustrative purposes.

\section{Findings}

\section{Goals and managerial approaches}

A number of reasons underlie the owner-managers' choice for running a B\&B. These reasons include becoming self-employed, responding to a business opportunity, complementing an existing income (e.g. farm, pension) as well as a means of socialising with guests. For those who used to live in the city, the B\&B was a means of supporting their life in the countryside. The choice of moving to Scotland was related to its unspoilt nature and wilderness, as explained by Meg:

It was never in my career plan to run a B\&B, but what was in my life plan was to come and live in Scotland, we have planned for many, many years that we wanted to live in the Highlands. 


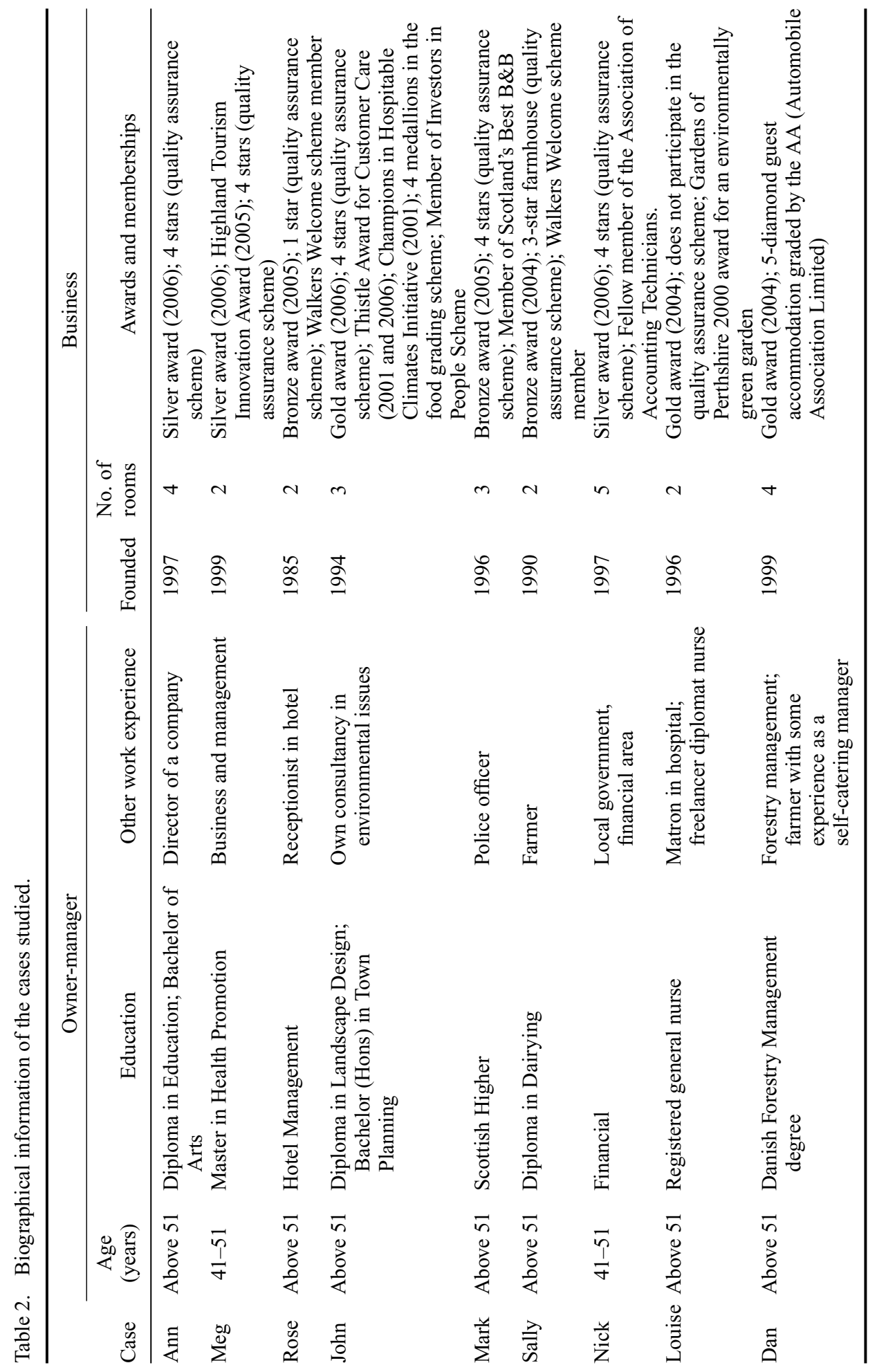


We had to wait until our youngest son had done his A levels and went to university, because it doesn't really matter where you live once they move to university. (...) and this house came on sale and the only way we could see we could buy it was to run it as a B\&B. So it was by default really that I am a B\&B landlady.

Perhaps predictably, owner-managers had both non-economic and economic goals for being in business. Non-economic goals encompass enjoying the lifestyle provided by the business, having personal satisfaction, making a difference and having a responsible business, whereas the economic goals were related to having financial independence. John, Nick and Dan balance both non-economic and economic goals to be in business and this was apparent in their semi-formal approach to the business, which can be characterised by investing more time in management, having developed a business plan, keeping business records and caring more about the quality of the service and the guests' experience. However, Rose and Sally are examples of informal approaches, who devoted little time to managing and "improving" their businesses. Instead, these owner-managers allocated more time to other activities, such as farm-related and community-related events, which seemed to be central to their lives. For Ann and Rose, in particular, the business was a means of socialising with other people and of learning about other cultures. In contrast to those with a semi-formal approach, Rose, Sally, Louise and Mark perceived the business to be an extension of their domestic life. Consequently, they did not make a distinction between business and household energy and water consumption; this behaviour contrasts with that adopted by Meg, John, Nick and Dan, who produce separate records for their businesses.

A common feature throughout the cases is the fact that they initiated their business when they were middle-aged, after having had a previous career. They did not have any managerial $\mathrm{B} \& \mathrm{~B}$ experience when they started, although they used their experience to inform their approach and develop a "concept" for the business; for example, experience as guests in other B\&Bs. Additionally, emphasis on particular aspects of the business may reflect the owner-managers' values as well as their outlook for the business. Meg, for example, aspires to be an interesting and personable host who provides low-cost accommodation for walkers, Nick likes to be seen as providing value for money to his guests and John wants his B\&B to be perceived as a family home.

The business approach was, then, influenced by the owner-managers' background. The skills acquired from prior managerial, financial and auditing work experience appear to have been useful in informing their semi-formal business approach. These owner-managers also seem to be more aware of the financial side of the business (e.g. profits). Conversely, the owner-managers who are least financially driven (Rose, John, Sally and Louise) seem to have adopted a more informal business approach and are less proactive in their decisions. In these cases, business management is kept to a minimum, because the time spent on business management is shared with other activities (e.g. managing the farm, community activities).

In all cases with more informal managing approaches, the bottom line for ownermanagers is having a business which they are able to control and manage within their wider interests and self-perceived abilities, as observed by John:

Because ... the bottom line is my time is as important as anything else and if I waste it that in itself isn't green, you follow? And that's where I'm coming from ... it's what's suitable for us to keep our lives ... comfortable, manageable that's the bottom line.

For the owner-managers least concerned with the financial side of the business, managing the B\&B has to deliver satisfaction. Therefore, they may not engage with managerial 
aspects that are perceived as not being pleasurable or/and challenging, such as energy monitoring and keeping updated records. In contrast to these cases, those with semi-formal approaches also gain satisfaction from managing those "Check and Act" activities (e.g. monitoring) that help them to assess their targets and receive feedback from their actions. As explained by Meg, the time and effort spent on tasks such as regular monitoring are not perceived as irrelevant or as a managerial burden, as envisaged by those with informal approaches:

We just take the business a sort of a structural approach to it. I got lists all over the place. I got a folder, I got spare sheets and I keep counting all my meter readings, sort out all the calculations, I mean that is just part of the business and I enjoy doing that. It is the benchmark, isn't it ... it means I have something to measure by.

The environmental management approach mirrors the one adopted in the management of a B\&B. Hence, those with semi-formal business approaches are generally more willing to invest time in actively improving their environmental performance, notably energy and water consumption, while those with an informal business approach tend to adopt environmental practices in small incremental steps. Environmental practices underlying a "Plan-CheckAct" reasoning (e.g. monitoring, keeping updated records), which is associated with an EMS approach, are ignored by informal businesses.

Therefore, spending time and effort in keeping separate records, as well as undertaking weekly consumption assessments (e.g. energy and water), is perceived as disproportionate, as explained by Louise:

I know that, with water monitoring ... I don't monitor my water ... I think I am too small a business to kind of think of things.

This reasoning contrasts with the one endorsed by the semi-formal businesses, which also value the possibility of cutting costs by adopting, for example, energy conservation practices. As Dan explains:

And cost, it is, cost is a most effective way, cost cutting is a most effective way of improving your profit immediately and cost cutting, yes ... there's two ways, you can do the passive one is to switch the light off and you're saving money and then you can do the other one, which is to go and invest in low energy bulbs. So there's two ways but if you're conscious about cost in one aspect, you're conscious about cost in all aspects (...).

In summary, it is possible to identify two groups of owner-managers with regard to their managerial approach: informal versus semi-formal. The levels of formality in adopting "Plan-Check-Act" managing practices, namely keeping records and monitoring consumption (e.g. energy, water), appears to follow the owner-managers' wider business approach. Indeed, the engagement of the least financially driven owner-managers with those types of environmental practices is unlikely to be effective.

\section{Expectations about adopting environmental practices}

The emphasis given by some owner-managers to certain environmental practices seems to be linked to how they perceive the environment. The businesses studied seem to have a similar understanding of the "environment", as they recurrently describe it by using features of their physical environment (e.g. air, water, hills, mountains, trees), natural environment (e.g. wildlife) and the condition of the environment (e.g. air quality). The environment is also described as being their surroundings and the place that they live in. In addition to these more "local" notions of the environment, some also discuss wider 
environmental issues, such as global warming and the aim to balance between human activities and the environment (e.g. John, Nick, Dan); others have specific elements that they associate with the word "environment", such as food (e.g. John) or quality of life (e.g. Rose). Environmental practices are understood as their way of protecting what they perceive to be the "environment" by not polluting it and by taking responsibility for their own actions. To Ann, it is also making sure that she is contributing to a better future for her children and grandchildren.

Being brought up in the countryside, moving to the countryside in adulthood, role models (family), participation in organisations and vocational experiences are all examples of sources of environmental sensitivity that have influenced the owner-managers' understanding of the "environment". However, positive experiences in nature and family role models are more prevalent in childhood, whereas work experience, participation in organisations, environmental degradation and moving to the countryside are sources of environmental sensitivity associated more with adulthood.

In all cases, personal expectations were important in guiding the adoption of environmental practices. These expectations can be grouped into non-economic/personal versus economic/practical expectations. Indeed, at a personal level, most cases value the "feel good" factor and satisfaction from the adoption of environmental practices; this is because they believe that they are actively contributing towards reducing their environmental impact. In these cases, expectations from adopting environmental practices are related to affective goals. Meg, John and Dan enjoy putting their environmental awareness into practice by exploring and adopting new measures; expectations of increasing their environmental knowledge and mastery are associated with their cognitive and task goals. Furthermore, Meg also expects, by adopting environmental practices, to be consistent with what she was brought up to believe as being a "good" person. Also, Dan and John believe that by adopting environmental practices, they are taking responsibility for their own actions.

Therefore, owner-managers with informal approaches, and with mainly a non-economic outlook for the business, endorse more readily those environmental practices that are consistent with their within-person and task goals and do not expect to obtain financial gains from it, as explained by Mark:

Absolutely nothing! It is a change of practice ... we advertise that we are ... (...) the bronze green award ... people may come because of that, I doubt it. (...) this is a personal thing rather than a business thing.

However, those owner-managers pursuing economic goals also expect to reduce their business costs by adopting environmental practices. Hence, environmental practices that can meet both non-economic and economic expectations are those where the owner-managers with semi-formal approaches felt more inclined to engage in and spend more time and effort in mastering, as Dan observes:

It was a big investment because we ... we had to buy, initially we bought ... about forty-five low energy bulbs and at four to five pounds, each ... but I was convinced that they would pay back. Because not only are they consuming lower energy, a lower amount of energy, but they're also lasting probably four or five times longer than ordinary light bulbs. (...) No, I self-funded it because I found the economy was so brilliant in doing it (...).

Hence, the owner-managers' expectations of adopting environmental practices seem to frame, to a certain extent, their environmental business agenda. Practices that fail to fulfil their personal expectations may be overlooked or reluctantly undertaken under duress rather than through understanding. 
Table 3. Type of practices and business characteristics.

\begin{tabular}{|c|c|c|}
\hline Reasoning & Example of practices & Business characteristics \\
\hline "Plan-Check-Act" & $\begin{array}{l}\text { Monitoring, keeping records and } \\
\text { separate "green file" }\end{array}$ & $\begin{array}{l}\text { Semi-formal managerial approach, } \\
\text { more professionally run, drive to } \\
\text { be efficient, enjoyment in } \\
\text { benchmarking and cutting costs }\end{array}$ \\
\hline "Do" & $\begin{array}{l}\text { Local products and purchase, } \\
\text { compost heap, grow one's own } \\
\text { vegetables, bird feeders, recycling, } \\
\text { wildlife walk, energy-saving bulbs, } \\
\text { providing environmental } \\
\text { information to guests }\end{array}$ & $\begin{array}{l}\text { Informal managerial approach, } \\
\text { adaptive mode, minimal approach } \\
\text { to the business, run on part-time } \\
\text { basis }\end{array}$ \\
\hline
\end{tabular}

\section{Managing inconsistencies between personal approaches and EMS requirements}

As stated earlier in this paper, the EMS reasoning includes quality improvement principles, which implicitly require planning, implementation, checking and application of corrective actions. It is the owner-managers with informal management approaches to the business who find measures that reflect "Plan-Check-Act" principles (Table 3) hard to implement. These owner-managers justify their lack of engagement with practices such as monitoring as getting in the way of really improving environmental performance, for some stated them as time-wasting paper-filling exercises. This example is consistent with Eckert and Bell's (2005) research, where non-conventional farmers rejected the advice and feedback from "experts" when it was inconsistent with their vision of farming.

Conversely, those cases with a management approach more consistent with the one encouraged by the certification scheme justified the adoption of new practices by valuing the advice and learning opportunities that the process of adopting environmental practices had offered; they were therefore more supportive of the scheme.

These examples illustrate the importance of considering owner-managers' different perceptions and understandings as well as environmental management approaches when encouraging environmental engagement. Support agencies may need to acknowledge that they are encouraging a certain vision of environmental management; however, ownermanagers may or may not share that vision. By developing a shared vision with their target audience, agencies and environmental schemes may raise their credibility close to that expected by the owner-managers, who would be more receptive to their advice with regard to environmental business improvement. This shared vision in engagement with learning opportunities, responsiveness to auditors' advice and adoption of new practices was evident in the owner-managers with semi-formal managerial approaches. Businesses with short-term reasoning would find it difficult to engage with practices that imply a long-term vision required for continual environmental improvement. Therefore, what is proposed by a scheme's criteria is perceived by informal businesses, such as the cases of Rose and John, as ill-suited for their managerial bottom line, i.e. having an enjoyable and manageable business.

In this research, the businesses with informal management approaches seemed to be more responsive to practices of "Do" reasoning (Table 3), which were acquired through formative experiences (e.g. experiences in nature, role models in childhood); these were familiar practices that required little reflection or planning. However, this situation does not mean that owner-managers are not adopting environmental practices; it just means that they are endorsing those practices that are consistent with their vision of the "environment" and 
that do not challenge their capabilities. Owner-managers with semi-formal management approaches and with a drive for efficiency find it easy and enjoyable to measure energy and water in search for savings.

\section{Conclusion}

The findings of this paper confirm and develop some of the insights gained by others who have examined small firms in tourism, particularly in the context of environmental engagement. The research found confirmatory evidence of lifestyle businesses running their operations in an informal manner and with little regard to, or recognition of, interventions designed to influence their behaviour. The owner-managers interviewed started their businesses because of various circumstances, during their middle age, when certain lifestyle choices were made. As others have already pointed out, understanding what prompts ownermanagers to run a business is essential to developing policy instruments if they are to be well received (e.g. Thomas et al., 2011).

Engaging in the kind of collaborative policymaking implied by these findings is challenging. Even though owner-managers had voluntarily joined GTBS, those who adopted the most informal approach to running their business were not persuaded of the value of using techniques associated with EMS as they were perceived as being time-consuming and inconsequential for the (small) size of their business. The anticipated gains delivered by environmental practices on a personal and practical level seem to play a key role in the engagement with those practices. Highlighting these as part of a strategy of encouraging ongoing collaboration and dialogue would seem appropriate.

The emphasis given to practices that can foster either personal or practical expectations also appears to reflect the owner-managers' rationale for the business. Indeed, at a personal level, they expect the adoption of environmental practices to give them a sense of "feeling good" about themselves. On a practical level, those who are more financially aware also expect to reduce their running costs when adopting environmental practices, whereas those least financially driven do not have such expectations.

Managerial approaches underlying the adoption of environmental practices may also give clues about how to encourage a valuable dialogue between agencies and small businesses. This dialogue requires the development of a shared vision, an essential factor for cooperation between agencies and small tourism businesses. The research findings support the notion that an increase in the shared vision enhances agencies' credibility and may lead owner-managers to cooperate more readily. The perception that agencies are genuinely mindful and flexible to attend to the idiosyncrasies of the business also seems to be an important factor in the development of a cooperative relationship between owner-managers and those agencies.

This research therefore has consequences for the development of pro-sustainability interventions, such as certification programmes. Though resource-intensive, consultants or mentors should try to understand owner-managers' assumptions based on their past actions and experiences because this would aid the development of tailored support and increase the acceptance of the guidance provided. Such understanding will also provide explanations for low uptake of practices that policymakers would assume make "business sense" and are promoted on the evidence of a business case. It can also provide explanations for why micro businesses do not broaden the type of sustainability activities they undertake but continue to act according to their values, prior knowledge and skills, and a balance between business and lifestyle goals. Support providers would also be better able to link 
environmental technical knowledge with owner-managers' expectations if they approached the issue in this manner.

\section{Note}

1. Estimating the size of the B\&B sector in the UK with a degree of reliability is notoriously difficult because of the way enterprises are classified (see Morrison \& Conway, 2007; Thomas, 2000). B\&Bs tend to exist in peripheral locations, where there is insufficient demand for larger businesses to prosper (often including rural settings).

\section{Notes on contributors}

Dr. Ana Rita Sampaio is a Postdoctoral Research Fellow at the Centre for Geographical Studies at Lisbon University, Portugal. She has been working on environmental engagement of small tourism businesses for over five years. Her research interests include sustainable tourism, environmental engagement and environmental management.

Rhodri Thomas is Professor of Tourism and Events Policy at the UK Centre for Events Management, Leeds Metropolitan University. His research interests include public policy studies, notably in the context of small businesses.

Dr. Xavier Font is the Director of Studies at the International Centre for Responsible Tourism, Leeds Metropolitan University. His research interest is market-led methods of engaging businesses towards sustainable change.

\section{References}

Anglada, M.L. (2000). Small and medium-sized enterprises' perceptions of the environment: A study from Spain. In R. Hillary (Ed.), Small and medium-sized enterprises and the environment: Business imperatives (pp. 61-74). Sheffield: Greenleaf Publishing.

Ateljevic, I., \& Doorne, S. (2000). Staying within the fence: Lifestyle entrepreneurship in tourism. Journal of Sustainable Tourism, 8(5), 378-392.

Beaver, G. (2002). Strategy and management in the smaller enterprise. Strategic Change, 11, 175-181.

Blackburn, R., \& Kovalainen, A. (2009). Researching small firms and entrepreneurship: Past, present and future. International Journal of Management Reviews, 11(2), 127-148.

Carlsen, J., Morrison, A., \& Weber, P. (2008). Lifestyle oriented small tourism firms. Tourism Recreation Research, 33(3), 255-263.

Chan, E.S.W. (2011). Implementing environmental management systems in small-and medium-sized hotels: Obstacles. Journal of Hospitality \& Tourism Research, 35(1), 3-23.

Clarke, J. (2004). Trade associations: An appropriate channel for developing sustainable practice in SMEs? Journal of Sustainable Tourism, 12(3), 194-208.

Darnall, N., \& Edwards, D. Jr. (2006). Predicting the cost of environmental management system adoption: The role of capabilities, resources and ownership structure. Strategic Management Journal, 27(4), 301-320.

Dewhurst, H., \& Thomas, R. (2003). Encouraging sustainable business practices in a non-regulatory environment: A case study of small tourism firms in a UK national park. Journal of Sustainable Tourism, 11(3), 201-213.

DiDomenico, M. (2005). Producing hospitality, consuming lifestyles: Lifestyle entrepreneurship in urban Scotland. In E. Jones \& C. Haven-Tang (Eds.), Tourism SMEs, service quality and destination competitiveness (pp. 109-122). Wallingford: CABI.

Dredge, D., \& Whitford, M. (2010). Policy for sustainable and responsible festivals and events: Institutionalisation of a new paradigm - A response. Journal of Policy Research in Tourism, Leisure and Events, 2(1), 1-13.

Duc, B.T. (2009). Tourism industry responses to the rise of sustainable tourism and related environemental policy initiatives: The case of Hue City, Vietnam Doctoral dissertation, Auckland University of Technology, New Zealand. 
Eckert, E., \& Bell, A. (2005). Invisible force: Farmers' mental models and how they influence learning and actions. Extension Journal, 43(3), 3FEA2.

Font, X. (2002). Environmental certification in tourism and hospitality: Progress, process and prospects. Tourism Management, 23(3), 197-205.

Font, X., \& Bendell, J. (2002). Standards for sustainable tourism for the purpose of multilateral trade negotiations. Madrid: World Tourism Organization.

Forsyth, T. (1995). Business attitudes to sustainable tourism: Self-regulation in the UK outgoing tourism industry. Journal of Sustainable Tourism, 3(4), 210-231.

Gerstenfeld, A., \& Roberts, H. (2000). Size matters: Barriers and prospects for environmental management in small and medium-sized enterprises. In R. Hillary (Ed.), Small and mediumsized enterprises and the environment: Business imperatives (pp. 106-118). Sheffield: Greenleaf Publishing.

Getz, D. (2009). Policy for sustainable and responsible festivals and events: Institutionalisation of a new paradigm. Journal of Policy Research in Tourism, Leisure and Events, 1(1), 61-78.

Getz, D., \& Carlsen, J. (2000). Characteristics and goals of family and owner-operated businesses in the rural tourism and hospitality sectors. Tourism Management, 21(6), 547-560.

Getz, D., \& Carlsen, J. (2005). Family business in tourism - State of the art. Annals of Tourism Research, 32(1), 237-258.

GTBS. (2011). The Green Tourism Business Scheme. Retrieved March 10, 2011, from http://www.green-business.co.uk

Hillary, R. (2000). Network for environmental management and auditing. In R. Hillary (Ed.), Small and medium-sized enterprises and the environment: Business imperatives (pp. 11-22). Sheffield: Greenleaf Publishing.

Honey, M. (Ed.) (2002). Ecotourism \& certification: Setting standards in practice. Washington, DC: Island Press.

Horobin, H., \& Long, J. (1996). Sustainable tourism: The role of the small firm. International Journal of Contemporary Hospitality, 8(5), 15-19.

Hukkinen, J. (1995). Corporatism as an impediment to ecological sustenance: The case of Finnish waste management [Analysis]. Ecological Economics, 15, 59-75.

Ingram, C. (2007). Certification in protected areas: A Western Australian case study. In R. Black \& A. Crabtree (Eds.), Quality assurance and certification on ecotourism (pp. 266-298). Wallingford: CABI.

International Hotels Environment Initiative (IHEI). (2005). Sowing the seeds of change. London: Author.

Jamal, T., Borges, M., \& Stronza, A. (2006). The institutionalisation of ecotourism: Certification, cultural equity and praxis. Journal of Ecotourism, 5(3), 145-175.

Kokkranikal, J.J., \& Morrison, A. (2002). Entrepreneurship and sustainable tourism: A case study of the houseboats of Kerala. Tourism and Hospitality Research, 4(1), 7-20.

Lane, B. (2009). Implementing sustainable tourism in Scotland: An interview. Journal of Sustainable Tourism, 17(6), 747-752.

McKeiver, C., \& Gadenne, D. (2005). Environmental management systems in small and medium businesses. International Small Business Journal, 23(5), 513-537.

McKercher, B., \& Robbins, B. (1998). Business development issues affecting nature-based tourism operators in Australia. Journal of Sustainable Tourism, 6(2), 173-188.

Medina, L.K. (2005). Ecotourism and certification: Confronting the principles and pragmatics of socially responsible tourism. Journal of Sustainable Tourism, 13(3), 281-295.

Morrison, A. (2006). A contextualisation of entrepreneurship. International Journal of Entrepreneurial Behaviour \& Research, 12(4), 192-209.

Morrison, A., Carlsen, J., \& Weber, P. (2008, 11-14 February). Lifestyle oriented small tourism [LOST] firms and tourism destination development. Paper presented at the CAUTHE Conference "Where the bloody hell are we?", Griffith Business School, Queensland, Australia.

Morrison, A., Carlsen, J., \& Weber, P. (2010). Small tourism business research: Change and evolution. International Journal of Tourism Research, 12(6), 739-749.

Morrison, A., \& Conway, F. (2007). The status of the small hotel firm. The Service Industries Journal, 27(1), 47-58.

Mottiar, Z. (2007). Lifestyle entrepreneurs and spheres of inter-firm relations: The case of Westport, Co. Mayo, Ireland. International Journal of Entrepreneurship and Innovation, 8(1), 67-74. 
Palmer, J. (2000). Helping small and medium-sized enterprises improve environmental management: Lessons from proactive small and micro firms. In R. Hillary (Ed.), Small and medium-sized enterprises and the environment: Business imperatives (pp. 325-342). Sheffield: Greenleaf Publishing.

Patton, M.Q. (2002). Qualitative research and evaluation methods. London: Sage.

Peters, M., \& Buhalis, D. (2004). Family hotel businesses: Strategic planning and the need for education and training. Education + Training, 46(8/9), 406-415.

Plummer, R., \& FitzGibbon, J. (2004). Some observations on the terminology in co-operative environmental management. Journal of Environmental Management, 70(1), 63-72.

Revell, A., \& Rutherfoord, R. (2003). UK environmental policy and the small firm: Broadening the focus. Business Strategy and the Environment, 12(1), 26-35.

Scott, D. (2011). Why tourism must address climate change. Journal of Sustainable Tourism, 19(1), $17-34$.

Shaw, G., \& Williams, A.M. (2004). From lifestyle consumption to lifestyle production: Changing patterns of tourism entrepreneurship. In R. Thomas (Ed.), Small firms in tourism: International perspectives (pp. 99-114). London: Elsevier.

Shaw, G., Williams, A.M., \& Greenwood, J. (1987). Tourism and the economy of Cornwall. Exeter: University of Exeter.

Sweeney, M., \& Lynch, P. (2009). Classifying commercial home hosts based on their relationship to the home. Tourism and Hospitality Planning and Development, 6(2), 159-170.

Thomas, R. (1998). The management of small tourism and hospitality firms. London: Cassell.

Thomas, R. (2000). Small firms in the tourism industry: Some conceptual issues. International Journal of Tourism Research, 2(5), 345-353.

Thomas, R., Shaw, G., \& Page, S. (2011). Understanding small firms in tourism: A perspective on research trends and challenges. Tourism Management, 32(5), 963-976.

Thwaites, R. (2007). The Australian Eco Certification Program (NEAP): Blazing a trail for ecotourism certification, but keeping on track? In R. Black \& A. Crabtree (Eds.), Quality assurance and certification in ecotourism (pp. 435-463). Wallingford: CABI.

Tilley, F. (2000). Small firms' environmental ethics: How deep do they go? In R. Hillary (Ed.), Small and medium-sized enterprises and the environmental: Business imperatives (pp. 35-48). Sheffield: Greenleaf Publishing.

Tribe, J., Font, X., Griffiths, N., Vickery, R., \& Yale, K. (2000). Environmental management for rural tourism and recreation. London: Cassell.

Tzschentke, N., Kirk, D., \& Lynch, P. (2008). Going green: Decisional factors in small hospitality operations. International Journal of Hospitality Management, 27(1), 126-133.

Vernon, J., Essex, S., Pinder, D., \& Curry, K. (2003). The "greening" of tourism micro-businesses: Outcomes of focus group investigations in South East Cornwall. Business Strategy and the Environment, 12, 49-69.

Vivanco, L.A. (2007). The prospects and dilemmas of indigenous tourism standards and certifications. In R. Black \& A. Crabtree (Eds.), Quality assurance and certification on ecotourism (pp. 218-240). Wallingford: CABI.

Weaver, D. (2011). Can sustainable tourism survive climate change? Journal of Sustainable Tourism, $19(1), 5-15$.

Yanow, D. (2000). Conducting interpretive policy analysis. Thousand Oaks, CA: Sage.

Yin, R.K. (2009). Case study research - Design and methods. London: Sage. 